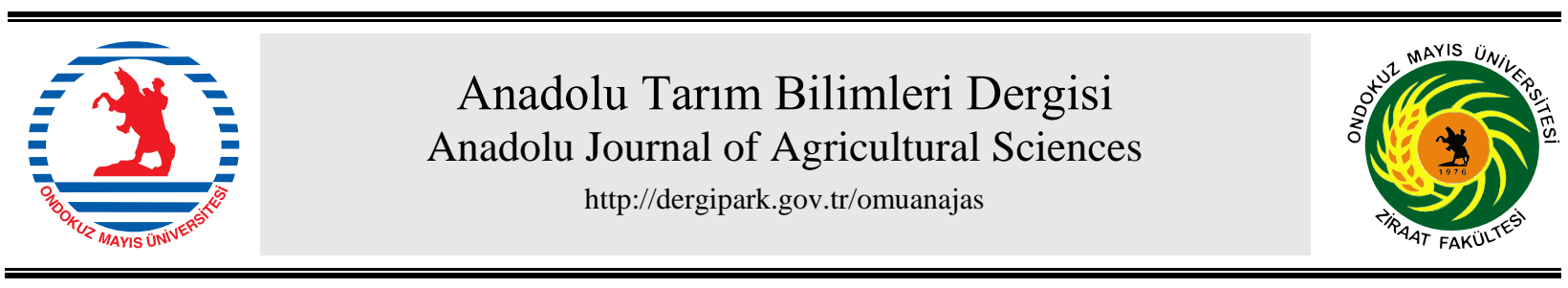

Araştırma/Research

Anadolu Tarım Bilim. Derg./Anadolu J Agr Sci, 35 (2020) ISSN: 1308-8750 (Print) 1308-8769 (Online) doi: $10.7161 /$ omuanajas. 608600

\title{
Orman üçgülü (Bituminaria bituminosa L.) Genotiplerinin Tuzluluğa Dayanıklılık Düzeylerinin Belirlenmesi
}

\author{
Gülcan Kaymak ${ }^{\mathrm{a}^{*}}$, Zeki Acar $^{\mathrm{a}}$ \\ ${ }^{a}$ Ondokuz Mayls Üniversitesi, Ziraat Fakültesi, Tarla Bitkileri Bölümü, Samsun, Türkiye
}

*Sorumlu yazar/corresponding author: gulcankaymak92@gmail.com

Geliş/Received 21/08/2019 Kabul/Accepted 03/01/2020

\begin{abstract}
ÖZET
Bu çalışma, Orta Karadeniz Bölgesinden toplanmış 85 adet Bituminaria bituminosa (Bitbit) genotipinin tuzluluğa dayanıklılık düzeylerinin belirlenmesi amacıyla, 2017 yılında Ondokuz Mayıs Üniversitesi, Ziraat Fakültesi Laboratuvar ve Seralarında yürütülmüştür. İki aşamalı olarak planlanan çalışmada, ilk aşamada 85 genotipe ait tohumlar sert tohum kabuğu giderildikten sonra farklı $\mathrm{NaCl}$ yoğunluklarında $(0$, $25,50,75$ ve $100 \mathrm{mM}$ ) çimlendirilmiştir. Tuz yoğunluğu arttıkça çimlenme oran1, kökçük ve sürgün uzunluğu ve ağırlıkları azalmıştır. Yüksek dozlarda bazı genotiplerde hiç çimlenme olmamıştır. İkinci aşamada ise en iyi sonuç veren 10 genotip seçilmiş ve bu 10 genotiple serada fide aşamasında aynı tuz yoğunluğu içeren çözeltiler kullanılarak çalışılmıştır. Sera çalışmalarında, yüksek NaCl yoğunluğuyla beraber topraktaki tuzluluk artmış, belirli bir süreden sonra 75 ve $100 \mathrm{mM}$ çözelti uygulanan bitkiler tamamen ölmüştür. Artan tuz yoğunlukları ile birlikte fidelerde bitki boyu, yaprak sayısı, bitki kök ve gövde ağırlığı azalmıştır. Yine tuz yoğunluğu arttıkça yapraklardaki klorofil a, klorofil b ve karotenoid miktarı azalırken, lipit peroksidasyonu ve prolin miktarının arttığı tespit edilmiştir.
\end{abstract}

Determination of Salinity Tolerance Levels of Tedera (Bituminaria bituminosa L.) Genotypes

\section{ABSTRACT}

This study was carried out to determine salinity resistance level of 85 Bitbit genotypes collected from Central Black Sea Region of Turkey, in OMU greenhouses and laboratories in 2017. The study was conducted in two steps. In the first step scarified seed of 85 genotypes were germinated in different $\mathrm{NaCl}$ concentrations $(0,25,50,75$ and $100 \mathrm{mM})$. As salt concentration increase germination ratio, length and weight of radicle and pedicel decreased. There was no germination for some genotypes in higher doses. In the second step, the best 10 genotypes selected and same salt concentrations applied to seedlings of those genotypes in greenhouse. Soil salinity increased with increasing $\mathrm{NaCl}$ concentration and, all plants in 75 and $100 \mathrm{mM} \mathrm{NaCl}$ treatments were failed after application of saline water for a while. With increasing salt concentration plant height, leaf number, root and stem weight of the plants decreased. As salt concentration increase, amount of chlorophyll a, chlorophyll $b$ and carotenoid of the leaves decreased while lipid peroxidation and prolin level increase.
Anahtar Sözcükler:

Bituminaria

bituminosa

karotenoid

klorofil

prolin

tuzluluk

Keywords:

Bituminaria

bituminosa

carotenoid

chlorophyll

prolin

salinity

(C) OMU ANAJAS 2020 


\section{Giriş}

Baklagiller familyasına ait çok yıllık bir bitki olan Bituminaria bituminosa kuraklık ve sicaklığa son derece dayanıklı olması, yaz ayları boyunca büyümesini sürdürebilmesi ve yeşilliğini koruması, marjinal alan olarak tanımlanan eğimli, taşlık, üst toprak tabakasını kaybetmiş, derinliği az olan topraklarda sulanmadan yetiştirilebilmesi nedeniyle üzerinde en çok durulan bitkilerden birisidir. Hayvanlar için önemli bir yeşil yem kaynağıdır. Anavatanı Akdeniz olmakla beraber, Türkiye, Güney Avrupa, Kırım, Batı Suriye, Kıbrıs, Kafkasya, İsrail, Kuzey Afrika, Portekiz, İspanya gibi ülkelerin doğal vejetasyonunda da geniş bir yayılım göstermektedir (Davis, 1965). Uzun y1llardan beri Kanarya Adaları ve Fas'ta tarımı yapılmakla birlikte, son y1llarda uygulanan projeler ve geliştirilen çeşitlerle Avusturalya'nın kurak batı bölgelerinde yetiştiriciliği giderek yaygınlaşmaktadır. Genel olarak açık yerlerde, yol kenarlarında, üst toprak tabakası kaybolmuş alanlarda, döküntü topraklı yamaçlarda, ağaçlık ve ormanlık alanlarda ve 4.7 ile 8.5 arasındaki pH'da yetişmektedir (Davis, 1965). Bunların yanında bitki sıcak ve kurak yaz aylarında yeşil kalabilme yeteneğine sahiptir (Acar ve ark., 2001). Bituminaria türleri üzerinde özellikle son yıllarda yoğun araștırmalar yapılmaktadır. Kanarya Adaları'nda Bituminaria bituminosa hayvanlar tarafından yoğun olarak otlatılmaktadır. Hayvanların yoğun baskısı ve otlatılmasına karşı bitki oldukça dayanıklıdır. Taze olarak tüketilmesinin yanı sıra kuru ot olarak da hayvanlara yedirilmektedir.

Tuzluluk; özellikle kurak ve yarı kurak iklim bölgelerinde yıkanarak yeraltı suyuna karışan çözünebilir tuzların yüksek taban suyuyla birlikte kapilarite yoluyla toprak yüzeyine çıkması ve buharlaşma sonucu suyun topraktan ayrılarak tuzun toprak yüzeyinde ve yüzeye yakın bölümünde birikmesi olayıdır (Ergene, 1982; Kara, 2002). Toprakta veya suda tuzluluk, bitki büyümesini ve verimliliğini olumsuz etkileyen önemli abiyotik stres faktörlerinden birisidir. Dünya üzerinde 800 milyon hektardan daha fazla alanın tuz stresinden etkilendiği, bu alanın dünya toplam kara alanının \%6'sına karşılık geldiği bilinmektedir (FAO, 2009). Tuz stresi bitkilerde, türe, bitkinin gelişim dönemindeki sürekliliğine ve etki süresine bağlı olarak, bitki-su ilişkilerini ve beslenme düzenini etkilemektedir. Tuz stresi sonucunda ortaya çıkan su, beslenme ve enerji düzenlerindeki dengesizliklerin her biri, hem birbirlerinden bağımsız olarak, hem de birbirlerinin etkilerini arttırarak bitki gelişimi, verim ve kalite üzerinde olumsuz etkilerde bulunmaktadır (Can, 1999).

Çevresel faktörler ve fizyolojik etkilerle birlikte meydana gelen tuza tolerans özelliğinin esas kaynağ kalıtsal unsurlardır. Tuza tolerans bakımından bitkiler arasında önemli farklılıklar olduğu kadar, aynı türe ait genotipler arasında da tuza tolerans bakımından farklılıklar bulunduğu bilinmektedir (Ashraf, 1994).
Abiyotik faktör olarak tuz stresi, bitkilerde çimlenme geriliğine, kök ve toprak üstü organlarının gelişiminin engellenmesine, ayrıca kök ve sap kuru ağırlıklarının azalmasına neden olmaktadır. $\mathrm{Bu}$ nedenle, tuzlu şartlarda ekonomik bir ürün üretebilen tuza toleranslı bitki tür ve çeşitlerinin belirlenmesine ihtiyaç duyulmaktadır (Epstein, 1985). Nitekim tuza dayanıklı çeşitlerin belirlenmesi ile ilgili çalışmalara gittikçe daha fazla önem verilmektedir. Wilson ve ark., (2006), 7 farklı konsantrasyonda hazırlanan artan tuzluluk seviyelerine (EC: 2.6-20.1 $\mathrm{dS} \mathrm{m} \mathrm{m}^{-1}$ ) 12 farklı Vigna unguiculata genotipinin büyüme tepkilerini inceleyen bir çalışmada ise, 2.6-20.1 dS m $\mathrm{m}^{-1}$ arasında değişen tuzluluğun fidelerin yaprak alanı, yaprak kuru ağırlığı, gövde kuru ağırlığı ve kök kuru ağırlığını önemli derecede azalttı̆̆

Birçok çalışma glisinbetain ve prolin gibi organik maddelerin sentezlenmesi ile strese tolerans arasında pozitif bir ilişki olduğunu göstermiştir (Ashraf ve Foolad, 2007). Prolin genellikle stres koşullarında birikimi gerçekleşen, bitkinin dayanım yeteneğini sağlaması bakımından bir indikatör görevini yapan, suda çözünebilir bir aminoasittir (Bian ve ark., 1988). Ozmolit olarak görev yapmasının yanında, hücrelerin stabilizasyonu, sitozolik pH'nın ayarlanması ve hidroksil radikallerinin düzenlenmesinde etkli bir organik maddedir (Matysik ve ark., 2002). Literatürde gösterilen bir diğer önemli parametre ise hücre zarında bulunan yağların (lipitlerin) peroksidasyonudur. Yağların peroksidasyonu, yaşayan her canlı organizmada meydana geldiği bilinen en zarar verici işlemler olarak nitelendirilmektedir. Çeşitli stresler altında, hücre zarındaki yıkım, bazen lipid yıkım seviyesinin tek belirleyicisi olarak ele alınır.

Bezelye, börülce ve hint baklası gibi çeşitli baklagillerde yapılan çalışmalarda, artan tuz yoğunluğunun yarattığı stres sonucu bitkilerde prolin ve lipit peksidasyon miktarının arttığı, klorofil a ve klorofil b miktarı ile birlikte çimlenme oranı, bitki kök ve yaş ağırlıkları gibi parametrelerin azaldığı belirlenmiştir (Shahid ve ark., 2012; Cha-um ve ark., 2013).

$\mathrm{Bu}$ çalışma da TÜBİTAK 111 O 651 nolu proje kapsaminda Samsun, Sinop ve Kastamonu illerinden toplanan Bituminaria bituminosa genotiplerinin tuzluluğa dayanıklıklık düzeylerinin belirlenmesi amaçlanmıştır. Toplamda 85 genotipe ait tohumlar 5 farklı NaCl yoğunluğunda (0-25-50-75-100 mM) ilk önce labaratuvar koşullarında çimlendirilmiş, daha sonra yüksek tuz yoğunluklarında en çok çimlenme görülen 10 genotiple serada fide aşamasında çalışılmıştır.

\section{Materyal ve Yöntem}

Samsun, Sinop ve Kastamonu illerinden 2008, 2009 ve 2012 y1llarında 85 farklı yerden toplanan Bituminari bituminosa' ya ait tohumlar OMÜ Ziraat Fakültesi'ne 
ait Deneme Alanına ekilmiş ilerleyen yıllarda bakım ve biçim işlemleri gerçekleşmiştir. Çalışmada 2015 y1lında elde edilen tohumlar kullanılmıştır. Tesadüf parselleri deneme desenine göre yürütülen bu çalışma iki aşamalı olarak kurulmuştur. İlk aşamada, 85 tane Bituminari bituminosa genotipine ait tohumlar zımparalanıp tohum kabuğu sertliği giderildikten sonra, farklı yoğunluktaki tuzlu çözeltiler kullanılarak çimlendirilmiştir.

Çimlendirme çalışmaları kontrollü şartlarda Nüve Growthchamber- GC400 marka iklim dolabı kullanılarak \% 60 nem ve $24^{\circ} \mathrm{C}^{\prime}$ de yapılmıştır. Çimlendirme testlerinde $\mathrm{NaCl}$ 'ün 0 (Kontrol), 25, 50, 75 ve $100 \mathrm{mM}$ yoğunluğa sahip çözeltileri kullanılmıştır. Çimlendirme çalışmasında Kontrol uygulamasında saf su kullanılmıştır. Her bir genotipe ait tohumlar 3 tekrarlı olmak üzere petri kaplarında kurutma kağıdı arasına 20 'şer tohum olacak şekilde yerleștirilmiştir. Her petri kabına iki günde bir $10 \mathrm{ml}$ olacak şekilde çözelti verilmiştir. Fungus gelişimini engellemek amaciyla çözeltilere 0.5 g 1-1 Captan 50 wp eklenmiştir. Daha sağlıklı bir çimlenme için kurutma kağıtları her iki günde bir değişmiş, petriler tamamen temizlendikten sonra yeniden çözelti eklenmiştir. Çimlendirme denemesinde çimlenme oranı, sürgün ağırlığı, kökçük uzunluğu, gövde uzunluğu özellikleri incelenmiştir. İkinci aşamada incelenen özellikler yönünden en iyi sonuç veren 10 genotip seçilerek bunlar serada saksı denemesinde kullanılmıştır. Seçilen genotiplerin tohumları viyollerde çimlendirildikten sonra fideler derinliği ve çap $120 \mathrm{~cm}$ olan saksılara şaşırtılmıştır. Her bir saksıya homojen olmak üzere $2: 1$ oranında $3 \mathrm{~kg}$ toprak:gübre karışımından oluşan harç konulmuştur. Saksılarda kullanılan toprağın kimyasal özellikleri Çizelge 3.2'de verilmiştir. Yapılan analizler sonucunda saksı toprağının EC'si hafif tuzlu toprak $(\mathrm{EC}=5.4 \mathrm{mS} / \mathrm{cm})$ olarak belirlenmiştir. Saksılar 10 gün boyunca musluk suyu ile sulanmıştır. Musluk suyu EC'si $1.5 \mathrm{mS} / \mathrm{cm}$ 'dir. Şaşırtma işleminden 10 gün sonra saksılar dozlara göre gruplandırılarak $0,25,50,75$ ve $100 \mathrm{mM}$ yoğunluğuna sahip çözeltiler sera sıcaklığı, hava ve saksı toprağının nem durumu, bitkinin evaporasyon ve transpirasyon durumları göz önünde bulundurularak her saksıya iki günde $150 \mathrm{ml}$ olacak şekilde verilmeye başlanmıştır. $\mathrm{Bu}$ işlem 4 hafta boyunca devam etmiştir. Sürenin sonunda 75 ve $100 \mathrm{mM}$ dozu uygulanan tüm bitkiler öldüğünden, kök ve gövdelerde uzunluk ve ağırlık ölçümleri yapılamamıştır. Ancak, tuzlu su uygulaması başladıktan 20 gün sonra, henüz tüm bitkiler ölmemiş olduğundan yapraklarda kimyasal analizler yapılabilmiştir.

Saksılarda kullanılan toprağın kimyasal analizleri Ondokuz Mayıs Üniversitesi Ziraat Fakültesi Toprak Bölümü Labaratuvarında yapılmıştır. Toprağın kimyasal özellikleri Çizelge 1' de verilmiştir.

Çizelge 1. Saksılarda kullanılan toprağın kimyasal analiz değerleri

Table 1. Chemical analysis values of soil used in pots

\begin{tabular}{cccc}
\hline $\mathrm{pH}$ & $\mathrm{EC}(\mu \mathrm{S} / \mathrm{cm})$ & Organik Madde $(\%)$ & $\mathrm{Ca}(\mathrm{meq} / 100 \mathrm{gr})$ \\
7.47 & 5397 & 5.72 & 22.3 \\
\hline $\mathrm{Mg}(\mathrm{meq} / 100 \mathrm{gr})$ & $\mathrm{P}\left(\mathrm{ppm} \mathrm{P}_{2} \mathrm{O}_{5}\right)$ & Toplam Azot $(\%)$ & $\mathrm{Nem}(\%)$ \\
24.18 & 101.03 & 0.39 & 7.6 \\
\hline
\end{tabular}

Sera denemesinde ise bitki boyu, yaprak sayıs1, gövde yaş-kuru ağırlığı, kök boğazı çapı, kök yaş-kuru ağırlığ 1 , Arnon (1949)' a göre pigmentlerin belirlenmesi, Heath ve Packer, (1968)'e göre lipit peroksidasyonu, Claussen, (2005)'e göre prolin miktarı ve saksı topraklarının elektriksel iletkenliği özellikleri incelenmiştir.

Elde edilen verilerin varyans analizi SPSS 17.0 programında yapılmış, aralarında farklılık olan ortalamalar Duncan Çoklu Karşılaştırma yöntemi ile 0.01 önem düzeyine göre gruplandırılmıştır.

\section{Bulgular ve Tartışma}

Çimlendirme çalışması sürecinde, 85 adet Bitbit genotipine ait tohumlar 5 farklı tuz yoğunluğunda çimlendirilmiş, genotiplerin artan tuzluluğa olan tepkileri saptanmıştır. Çalışmada, genotiplere ait çimlenme oranı, sürgün ağırlığı, kökçük ve gövde uzunlukları ölçülmüştür. Çalışmaya ait sonuçlar Çizelge 2' de verilmiştir.

Genotiplerin ortalaması olarak tuz yoğunlukları karşılaştırıldığında, en yüksek çimlenme oranı kontrol grubunda tespit edilmiştir. Tüm dozlar birbirinden istatistiksel olarak farklı bulunmuştur. Kontrol grubundaki ortalama çimlenme oranı \%56.86 iken, bu değer artan tuz yoğunluklarına bağlı olarak azalmış ve $100 \mathrm{mM}$ dozunda \%14.51 oranına inmiştir (Çizelge 2). Benzer şekilde, Zennouhi ve ark. (2018)'nın Fas'ta yaptıkları çalışmada artan tuz yoğunluğuna bağlı olarak Bitbit tohumlarında çimlenme oranının düştüğü belirlenmiştir.

Artan tuz yoğunluğu ile birlikte ortamın osmotik basıncı da arttığından tohumların su alıp çimlenmesi zorlaşmakta ve ortalama çimlenme süresi uzamaktadır (Steppuhn ve ark., 2001; Duan ve ark., 2004). Nitekim, artan tuz yoğunluklarının çimlenme oranını azalttığı birçok araştırıcı tarafindan da tespit edilmiştir (Kaya ve İpek, 2003; Öz ve Karasu, 2007; Dumlupınar, 2005; Day ve ark., 2008; Kusvuran, 2015; Önal Aşçı ve Üney, 
2016). Bu çalışmada da artan tuz yoğunluklarına paralel olarak çimlenme oranı azalmış ortalama çimlenme süresi uzamıştır. Çimlenme süresi Kontrol grubunda 9 günde tamamlanırken, $25,50,75$ ve $100 \mathrm{mM}$ dozlarında çimlenme sirasıyla $24,26,29$ ve 32 günde tamamlanmıştır.

En yüksek sürgün ağırlığı kontrol grubunda tespit edilmiştir. Kontrol grubunda ortalama sürgün ağırlığg $0.31 \mathrm{~g}$ iken, en düşük sürgün ağırlığ $100 \mathrm{mM}$ dozunda $0.16 \mathrm{~g}$ olarak tespit edilmiştir. İstatistiksel açıdan $25 \mathrm{ve}$ $50 \mathrm{mM} \mathrm{NaCl}$ dozları sürgün ağırlığı bakımından aynı grupta yer alırken, diğer dozlar arasındaki farklılık önemli bulunmuştur. Tuz yoğunluğu arttıkça sürgün ağırlığı değerleri azalmıştır (Çizelge 2).

Tuz yoğunlukları karşılaştırıldığında en yüksek kökçük uzunluğu Kontrol ve $25 \mathrm{mM}$ uygulamalarında görülmüştür. $\mathrm{Bu}$ dozlarda kökçük uzunluğu değeri sirasıyla 2.13 ve $2.23 \mathrm{~cm}$ olarak ölçülmüsşür. En yüksek doz olan $100 \mathrm{mM}$ ' da ise bu değer $1.01 \mathrm{~cm}$ ' ye düşmüştür. Tuz yoğunlukları karşılaştırıldığında, en yüksek gövde uzunluğu Kontrol ve $25 \mathrm{mM}$ uygulamasında görülmüştür. $\mathrm{Bu}$ dozlarda gövde uzunluğu sırasıyla 4.37 ve $4.80 \mathrm{~cm}$ olarak ölçülmüştür.

50 ve $75 \mathrm{mM}$ dozlarında ortalama gövde uzunlukları, sirasiyla 2.90 ve $2.57 \mathrm{~cm}$ olurken, en yüksek doz olan $100 \mathrm{mM}$ ' da ortalama $2.34 \mathrm{~cm}$ olarak ölçülmüştür (Çizelge 2). Çimlenme özellikleri yönünden genotipler arasında önemli farklılıkların olduğu saptanmıştır.

Sonuçta, tuzluluğa en olumlu tepki gösteren 10 genotip seçilmiştir. Bu genotipler sırasıyla $7,8,11,13$, $15,33,56,71,77$ ve 78 numaralı genotiplerdir. Seçilen bu genotipler sera denemesinin materyalini oluşturmuştur. Sera çalışmasında da, $0,25,50,75$ ve $100 \mathrm{mM} \mathrm{NaCl}$ yoğunluklarına sahip çözeltiler saksılarda bulunan bitkilerin kök bölgesine verilmiştir.

Çizelge 2. Farklı NaCl yoğunluklarının Bitbit genotiplerinde (85 adet) çimlenme oranı, sürgün ağırlığı, kökçük ve gövde uzunluğuna etkisi*

Table 2. Effect of different $\mathrm{NaCl}$ concentrations on germination rate, shoot weight, root and stem length of bitbit genotypes $(85)^{*}$

\begin{tabular}{lcccc}
\hline Tuz Yoğunluğu & $\begin{array}{c}\text { Çimlenme Oranı } \\
(\%)\end{array}$ & $\begin{array}{c}\text { Sürgün } \\
\text { Ağırlığ }(\mathrm{g})\end{array}$ & $\begin{array}{c}\text { Kökçük Uzunluğu } \\
(\mathrm{cm})\end{array}$ & $\begin{array}{c}\text { Gövde Uzunluğu } \\
(\mathrm{cm})\end{array}$ \\
\hline Kontrol & $56.86 \mathrm{a}$ & $0.31 \mathrm{a}$ & $2.13 \mathrm{ab}$ & $4.37 \mathrm{ab}$ \\
$25 \mathrm{mM}$ & $44.10 \mathrm{~b}$ & $0.28 \mathrm{~b}$ & $2.23 \mathrm{a}$ & $4.80 \mathrm{a}$ \\
$50 \mathrm{mM}$ & $32.20 \mathrm{c}$ & $0.26 \mathrm{~b}$ & $1.83 \mathrm{~b}$ & $2.90 \mathrm{c}$ \\
$75 \mathrm{mM}$ & $25.54 \mathrm{~d}$ & $0.20 \mathrm{c}$ & $1.60 \mathrm{c}$ & $2.57 \mathrm{~cd}$ \\
$100 \mathrm{mM}$ & $14.51 \mathrm{e}$ & $0.16 \mathrm{~d}$ & $1.01 \mathrm{~d}$ & $2.34 \mathrm{~d}$ \\
\hline
\end{tabular}

*Aynı sütunda aynı harfle gösterilen değerler arasında 0.01 düzeyinde farklılık yoktur

Çizelge 3. Sera denemesinde $\mathrm{NaCl}$ uygulamasının bitkilerin morfolojik özelliklerine etkisi*

Table 3. The effect of $\mathrm{NaCl}$ application on the morphological characteristics of plants in greenhouse experiment*

\begin{tabular}{lccccc}
\hline $\begin{array}{c}\text { Tuz } \\
\text { Yoğunluğu }\end{array}$ & $\begin{array}{c}\text { Bitki Boyu } \\
(\mathrm{cm})\end{array}$ & $\begin{array}{c}\text { Yaprak ayısı } \\
\text { (Adet/bitki) }\end{array}$ & $\begin{array}{c}\text { Kök Boğazı Çap1 } \\
(\mathrm{mm})\end{array}$ & $\begin{array}{c}\text { Kök kuru ağırlığı } \\
(\mathrm{g})\end{array}$ & $\begin{array}{c}\text { Gövde Kuru } \\
\text { Ağırlığ } \\
(\mathrm{g})\end{array}$ \\
\hline Kontrol & $15.81 \mathrm{a}$ & $58.40 \mathrm{a}$ & $15.02 \mathrm{a}$ & $4.08 \mathrm{a}$ & 2.71 \\
$25 \mathrm{mM}$ & $13.53 \mathrm{ab}$ & $46.60 \mathrm{~b}$ & $14.41 \mathrm{a}$ & $3.07 \mathrm{a}$ & 2.13 \\
$50 \mathrm{mM}$ & $12.46 \mathrm{~b}$ & $41.67 \mathrm{bc}$ & $7.48 \mathrm{~b}$ & $1.18 \mathrm{~b}$ & 1.7 \\
$75 \mathrm{mM}$ & - & - & - & - & - \\
$100 \mathrm{mM}$ & - & - & - & - & - \\
\hline
\end{tabular}

*Aynı sütunda aynı harfle gösterilen değerler arasında 0.01 düzeyinde farklılık yoktur.

Çizelge 3'ü incelediğimizde, artan tuz yoğunluklarıyla beraber 75 ve $100 \mathrm{mM}$ grubundaki bitkiler tamamen öldüğü için, bu dozlara ilişkin olarak bitki boyu ve yaprak sayısı değerleri alınamamıştır. Bitki boyu değerleri yönünden ölçüm yapılabilen uygulamalar arasında çok önemli farklılıklar saptanmıştır. En yüksek ortalama bitki boyu değeri Kontrol $(15.81 \mathrm{~cm})$ ve $25 \mathrm{mM} \mathrm{NaCl}(13.53 \mathrm{~cm})$ uygulamasında belirlenmiş̧tir. Artan tuz yoğunluğu ile birlikte hem bitkilerin su alımı, hem de fizyolojik faaliyetleri engellendiğinden, bitkiler daha kısa boylu gelişmişlerdir (Sharma ve ark., 2005; Karakullukçu ve Adak, 2008).

Yaprak sayısı yönünden uygulamalar arasında çok önemli farklılıklar tespit edilmiştir. Uygulama sonucunda en yüksek yaprak sayısı kontrol grubunda belirlenmiştir (58.4). Her ne kadar tuz yoğunluğu artıkça yaprak sayısında bir azalma olsa da, 25 ve 50 
$\mathrm{mM}$ dozları arasındaki farklılık istatistiksel yönden önemli bulunmamıştır. Yem bitkilerinde bitki yaprak sayısı verim ve kalite açısından çok önemli bir unsur olarak değerlendirilmektedir (Acar ve Ayan, 2012). Artan tuz yoğunluğuna bağlı olarak bitkiler strese girmiş, klorofil miktarı azalmış, azalan fotosentez ve diğer fizyolojik faaliyetlerin sonucu olarak (Lacerda ve ark., 2003; Adavi ve ark., 2007) yaprak sayısında azalmalar olmuştur.

Kök boğazı çap1 yönünden genotiplerin ortalaması olarak uygulamalar arasında çok önemli farklılık olduğu belirlenmiştir.

Artan $\mathrm{NaCl}$ yoğunluğuyla birlikte bitkilerin kök boğazı çap1 azalmıştır. En geniş kök boğazı çapı Kontrol grubu ve $25 \mathrm{mM}$ uygulamasinda, sirasiyla 15.02 ve $14.41 \mathrm{~mm}$ olarak ölçülmüştür.

Diğer morfolojik özelliklerde olduğu gibi, artan tuz yoğunluğu bitkilerin fizyolojik özelliklerini engelleyip, morfolojik ölçüm değerlerini azaltmıştır (Lacerda ve ark., 2003; Adavi ve ark., 2007).
Kök kuru ağırlığı bakımından genotiplerin ortalaması olarak tuz uygulamaları arasında çok önemli farklılık bulunmuştur.

Artan $\mathrm{NaCl}$ yoğunluklarıyla beraber genotiplerin kök kuru ağırlıkları azalmıştır. Her ne kadar $25 \mathrm{mM}$ uygulamasında sayısal olarak bir azalma görülse de, Kontrol grubu ile aralarındaki farklılık önemsiz bulunmuştur. $50 \mathrm{mM}$ dozu uygulanan bitkilerin kök ağırlıklarında çok keskin bir azalma ortaya çıkmıştır.

Artan tuz yoğunluğuyla birlikte genotiplerin gövde kuru ağırlık değerleri azalmış, ancak bu azalma istatistiki açıdan önemli bulunmamıştır. Bu sonuç, kök gelişimi ile karşılaştırılınca, artan tuz yoğunluğundan bitki sürgün gelişiminin daha az etkilendiğini göstermektedir.

Elde edilen sonuçlar, artan tuzluluk düzeylerinin kök gelişimi üzerine olan etkisinin gövdeden daha fazla olduğunu göstermektedir (Zeinali ve ark., 2002; Eroğlu, 2007).

Çizelge 4. Bitbit genotiplerinin yapraklarında belirlenen klorofil, lipit peroksidasyonu ve prolin miktarı ortalama değerleri*

Table 4. Chlorophyll, lipid peroxidation and proline levels found in the leaves of Bitbit genotypes *

\begin{tabular}{cccccc}
\hline Tuz Yoğunluğu & $\begin{array}{c}\text { Klorofil a } \\
(\mathrm{mg} / \mathrm{g})\end{array}$ & $\begin{array}{c}\text { Klorofil b } \\
(\mathrm{mg} / \mathrm{g})\end{array}$ & $\begin{array}{c}\text { Karotenoid } \\
(\mathrm{mg} / \mathrm{g})\end{array}$ & $\begin{array}{c}\text { Lipit Peroksidasyonu } \\
\left(\mathrm{nmol} \mathrm{g}^{-1}\right)\end{array}$ & $\begin{array}{c}\text { Prolin } \\
\left(\mu \mathrm{mol} \mathrm{g}^{-1}\right)\end{array}$ \\
\hline Kontrol & $0.0060 \mathrm{a}$ & $0.0026 \mathrm{ab}$ & $0.0031 \mathrm{a}$ & $0.0096 \mathrm{c}$ & $0.11 \mathrm{~b}$ \\
$25 \mathrm{mM}$ & $0.0061 \mathrm{a}$ & $0.0029 \mathrm{a}$ & $0.0030 \mathrm{a}$ & $0.0117 \mathrm{~b} \mathrm{c}$ & $0.07 \mathrm{~b}$ \\
$50 \mathrm{mM}$ & $0.0045 \mathrm{~b}$ & $0.0018 \mathrm{a}-\mathrm{c}$ & $0.0019 \mathrm{~b}$ & $0.0096 \mathrm{c}$ & $0.13 \mathrm{ab}$ \\
$75 \mathrm{mM}$ & $0.0012 \mathrm{c}$ & $0.0009 \mathrm{c}$ & $0.0007 \mathrm{c}$ & $0.0163 \mathrm{~b}$ & $0.17 \mathrm{a}$ \\
$100 \mathrm{mM}$ & $0.0023 \mathrm{c}$ & $0.0016 \mathrm{bc}$ & $0.0012 \mathrm{c}$ & $0.028 \mathrm{a}$ & $0.13 \mathrm{ab}$ \\
\hline
\end{tabular}

* Aynı sütunda aynı harfle gösterilen değerler arasında 0.01 düzeyinde farklılık yoktur.

Bitbit genotiplerinin yapraklarında belirlenen klorofil a, klorofil b ve karotenoid değerleri Çizelge 4'te verilmiștir. Her üç pigment yönünden de tuz yoğunluğu uygulamaları arasında çok önemli farklılıklar tespit edilmiştir. Tuz yoğunluğu arttıkça her üç pigmentin yapraklardaki miktarı azalmıştır. Özellikle $50 \mathrm{mM}$ dozundan sonra klorofil a miktarında ortaya çıkan azalış çok belirgindir. Ancak, $75 \mathrm{mM}$ 'dan sonra pigment miktarında yeniden artış olmuş, fakat bu artış istatistiksel yönden anlamı bulunmamıştır. Kontrol ile $25 \mathrm{mM}$ dozu arasında pigment yoğunluğu yönünden anlamlı bir farklılık oluşmamıştır.

Hatta istatistiksel açıdan önemsiz olmakla birlikte 25 $\mathrm{mM}$ dozunda hafif bir artı̧̧ görülmüştür (Şekil 1). 75 ve $100 \mathrm{mM}$ dozlarında belirlenen pigment miktarları aynı istatistik grup içinde yer almışlardır.
Lipit peroksidasyonu yönünden uygulamalar arasında çok önemli farklılıklar olduğu saptanmıştır. Ortamdaki $\mathrm{NaCl}$ yoğunluğu arttıkça bitkide lipit peroksidayonu da artmıştır. En yüksek lipit peroksidasyon değeri $100 \mathrm{mM}$ ' da $0.028 \mathrm{nmol} \mathrm{g}-1$ iken, en düşük değer Kontrol, 50 ve $25 \mathrm{mM}$ ' da, sırasiyla $0.0096,0.0096$ ve $0.0117 \mathrm{nmol} \mathrm{g}-1$ olarak tespit edilmiştir.

Yapılan birçok çalışmada da artan $\mathrm{NaCl}$ yoğunluğuna paralel olarak lipit peroksidasyonu miktarı artmıştır (Babakhani ve ark., 2011; Shahid ve ark., 2012 ).Artan tuz yoğunluğuyla beraber Bitbit genotiplerinin yapraklarında belirlenen prolin miktarı artmış ve bu artış istatistiki açıdan önemli bulunmuştur. 


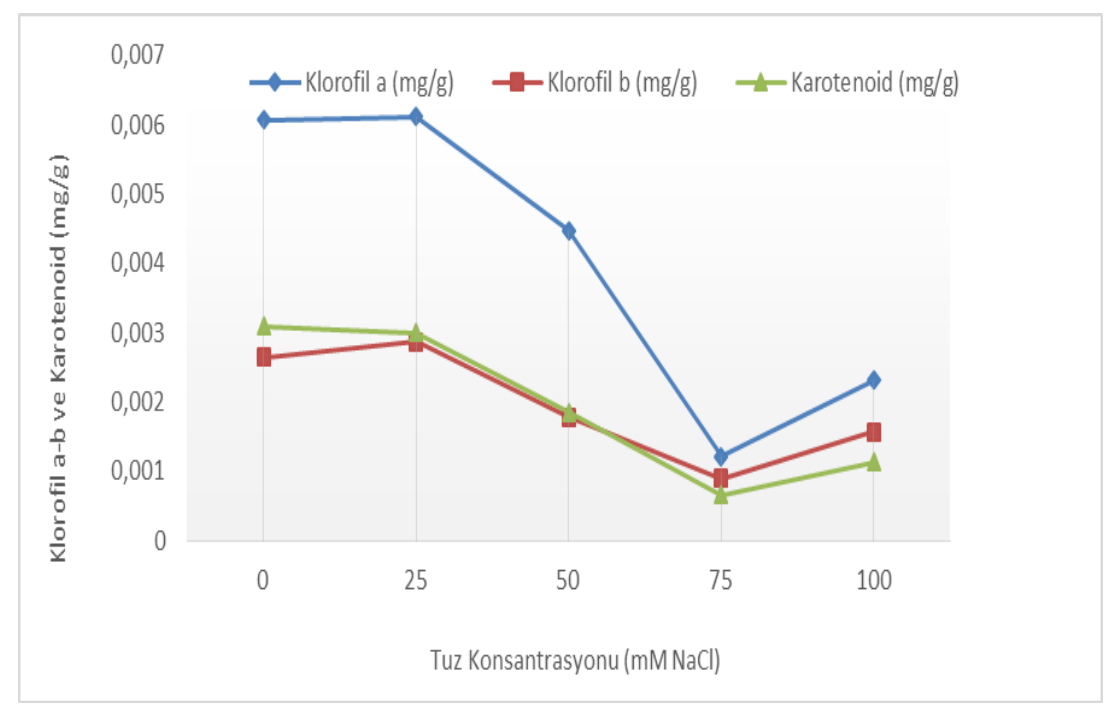

Şekil 1. Bitbit genotiplerinin yapraklarında belirlenen pigment değerleri $(\mathrm{mg} / \mathrm{g})$

Figure 1. Pigment values determined in the leaves of Bitbit genotypes $(\mathrm{mg} / \mathrm{g})$

En yüksek prolin miktarı 100, 75 ve $50 \mathrm{mM}$ gruplarında sirasıly $0.13,0.17$ ve $0.13 \mu \mathrm{mol} \mathrm{g}-1$ olarak bulunurken, en düşük prolin birikimi kontrol ve $25 \mathrm{mM}$ uygulamasında sirasiyla 0.11 ve $0.07 \mu \mathrm{mol} \mathrm{g}-1$ olmuştur (Çizelge 4, Şekil 2).

Prolin genellikle stres koşullarında birikimi gerçekleşen, bitkinin dayanım yeteneğini sağlaması bakımından bir indikatör görevini yapan, suda çözünebilir bir aminoasittir.
Foster at al. (2014), yaptıkları çalışmada kuraklık stresine maruz bıraktıkları Bitbit bitkisinde yapraklarda prolin birikiminin arttığını tespit etmişlerdir.

Tuzluluk stresine maruz bırakılan bu çalışmada da benzer sonuçlar elde edilmiş̧ir. Birçok araştırmacı tarafından da stres koşullarında bitkide prolin içeriğinin arttığ belirlenmiştir (Cha-um ve ark., 2013; Talukdar, 2013).

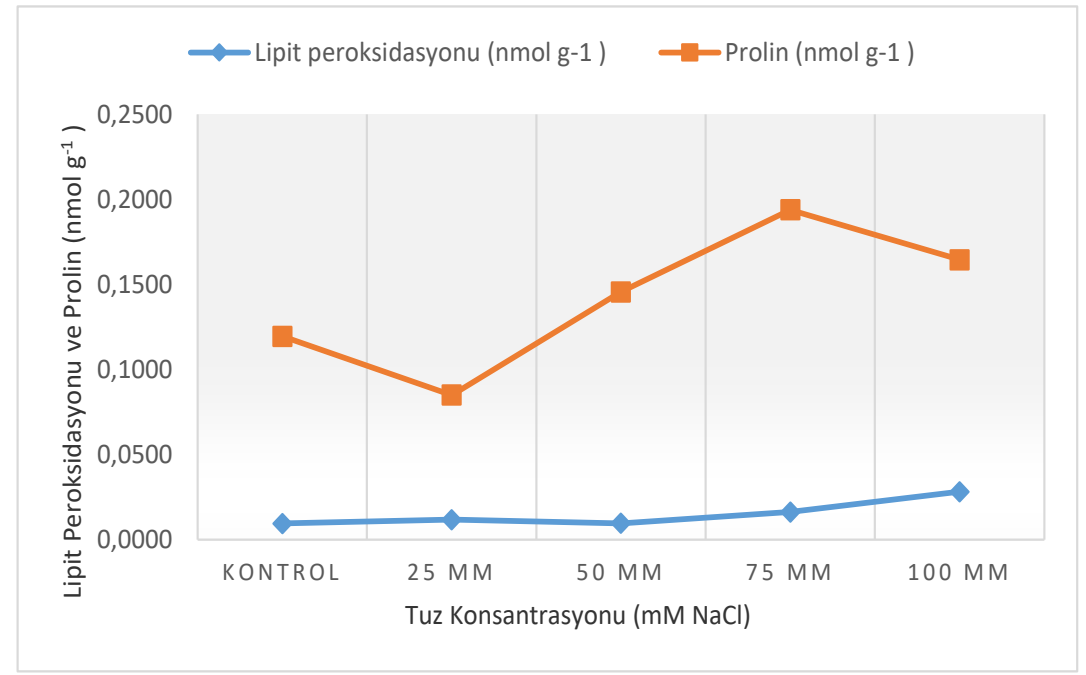

Şekil 2. Bitbit genotiplerinin yapraklarında belirlenen lipit peroksidasyonu ve prolin miktarı $\left(\mathrm{nmol} \mathrm{g}^{-1}\right)$

Figure 2. Lipid peroxidation and proline content determined in the leaves of Bitbit genotypes (nmol $\mathrm{g}-1$ ) 
Çizelge 5. Deneme sonunda saksı topraklarında belirlenen elektriksel iletkenlik (EC) değerleri (mS/cm)

Table 5. At the end of the experiment, the electrical conductivity (EC) values determined in the potting soil $(\mathrm{mS} / \mathrm{cm})$

\begin{tabular}{cc}
\hline Uygulama & EC $(\mathrm{mS} / \mathrm{cm})$ \\
\hline Kontrol & 4.688 \\
$25 \mathrm{mM}$ & 10.888 \\
$50 \mathrm{mM}$ & 14.902 \\
$75 \mathrm{mM}$ & 20.716 \\
$100 \mathrm{mM}$ & 22.928 \\
\hline
\end{tabular}

Çizelge 5'te de görüldüğü gibi tuz yoğunluğu arttıkça toprakta biriken tuz miktarı ve bunun göstergesi olan EC değerleri de artmıştır. En yüksek iki doz olan 75 ve $100 \mathrm{mM}$ uygulamalarında ilerleyen dönemlerde canlı bitki kalmamıştır. Özaslan Parlak (2008), sulama suyu tuzluluğunun korunganın (Onobrychis viciifolia Scop.) verimi ve kalitesi üzerine olan etkilerini ortaya koymak amacıyla yapılan çalışmada, 5 sulama suyu

\section{Sonuç}

Tuzluluk stresi koşullarında genotiplerin gösterdikleri kimyasal ve morfolojik tepkiler yönünden aralarında önemli farkl1l1klar olmakla birlikte, sulama suyuyla verilen $\mathrm{NaCl}^{\prime} l e$ beraber saksilardaki tuzluluk artmış en yüksek $\mathrm{NaCl}$ yoğunluğuna sahip 75 ve 100 $\mathrm{mM}$ grubundaki bitkiler tamamen ölmüştür. Her iki grupta da en son ölenler 56 ve 78 numaralı genotipe ait bitkiler olmuştur. Bu genotiplerden 56 numara SamsunBağkur, 78 numara Samsun-Ladik-Toptepe arasından toplanmıştır. Tuz yoğunluğu belirli bir düzeye kadar olan toprakların değerlendirilmesi ve ıslahı açısından, seçilecek genotipler kullanılabilir. Ancak, daha dayanıklı çeşitlerin geliştirilebilmesi için çalışmaların sürdürülmesi yararlı olacaktır.

\section{Teşekkür}

$\mathrm{Bu}$ çalışma OMÜ BAP tarafindan PYO.ZRT.1904.16.004 proje numarası ile desteklenmiştir. $\mathrm{Bu}$ makaledeki veriler Gülcan KAYMAK' in Yüksek Lisans Tezinden alınmıştır.

\section{Kaynaklar}

Acar, Z., Ayan, İ., 2012. Yem Bitkileri Kültürü. Ondokuz Mayıs Üniversitesi Ziraat Fakültesi Ders Kitab1, No: 2, Samsun

Acar, Z., Ayan, İ., Gülser, C., 2001. Some morphological and nutritional properties of legumes under natural conditions. Pakistan Journal of Biological Sciences. 4 (11): 1312 - 1315.

Adavi, Z., Mobil, M., Razmjoo, K., Landi, E., 2007. Effects of Salinity of Irrigation Water on Cynodon Spp. Cultivars Grown on Salinity Soil in Isfahan. J.Sci and Technol. Agric and Natur. 10: 4. tuzluluğu $\left(0.2,3.5,, 10\right.$ ve $\left.13 \mathrm{dS} \mathrm{m}^{-1}\right)$ kullanmışlardır. Artan tuz miktarı ile beraber bitki boyunun kısaldığını, kuru ot verimi ve ham protein oranının azaldığını belirtmişlerdir. En yüksek tuz yoğunluğunda canlı bitki kalmadığını ve sulama suyu tuzluluğunun artışına bağlı olarak toprak tuzluluğunun artış gösterdiğini rapor etmişlerdir.

Arnon, G.L., 1949. Copper enzyme in isolated chloroplasts:Polyphenol oxidase in Beta vulgaris. Plant Physiology, 24, 1-15.

Ashraf, M. 1994. Breeding for Salinity Tolerance in Plants. CRC Critical Reviews in Plant Sciences, 13: 17-42.

Ashraf, M., and Foolad, M.R., 2007. Roles of Glycine Betaine and Proline in Improving Plant Abiotic Stress Resistance. Envionmental and Experimental Botany, 59: 206-216.

Babakhani B, Khavari-Nejad R, Hassan sajedi R, Fahimi H, Saadatmand S. 2011. Biochemical responses of Alfalfa (Medicago sativa L.) cultivars subjected to $\mathrm{NaCl}$ salinity stress. African Journal of Biotechnology. Sep;10(55):11433-41.

Bian, Y.M., Chen, S.Y., Xie, M.Y., 1988. Effects of HF on Proline of Some Plants, Plant Physiology Communications, 6, 19-21.

Can, H.Z., 1999, Satsuma Mandarininde (Citrus Unshiu Marc) Tuzluluğun Verim ve Kalite Öğelerine Etkileri Üzerinde Araştırmalar.Doktora Tezi, Ege Üniversitesi Fen Bilimleri Enstitüsü, s.205, İzmir.

Cha-um S, Batin CB, Samphumphung T, Kidmanee C. 2013. Physio-morphological changes of cowpea (Vigna unguiculata Walp.) and jack bean (Canavalia ensiformis (L.) DC.) in responses to soil salinity. Ausralian Journal of Crop Science. 7(13):2128-35.

Claussen, W. 2005. Proline as a measure of stress in tomato plants. Plant Science, 168, 241-248.

Davis, P.H., 1965. Flora of Turkey And The East Aegean Islands. 1965 - 1988. 1 (1965); 2 (1967); 3 (1970); 4 (1972); 5 (1975); 6 (1978); 7 (1982); 8 (1984); 9 (1985); Edinburgh Univ. Press. Edinburgh.

Day, S., Kaya, M.D., Kolsarıcı, Ö. 2008. Bazı çerezlik ayçiçeği (Helianthus annuus L.) genotiplerinin çimlenmesi üzerine $\mathrm{NaCl}$ konsantrasyonlarının etkileri. Ankara Üniversitesi Ziraat Fakültesi Tarım Bilimleri Dergisi, 14 (3); 230-236. 
Duan D, Liu X, Khan MA, Gul B. 2004. Effects of salt and water stress on the seed germination of Chenopodium glaucum L. Pak J Bot. 36(4):793800.

Dumlupınar, Z. 2005. Elektrik akımı ve tuz konsantrasyonlarını makarnalık buğdayda çimlenmeye etkisi. Yüksek Lisans Tezi, K.S.Ü Fen Bilimleri Enstitüsü, s. 44, Kahramanmaraş.

Epstein, E., 1985. Salt-tolerant crops: origin, development, and prospects of the concept. Plant and Soil, 89, 187-198.

Ergene, A., 1982. Toprak Bilgisi. Atatürk Üniversitesi Ziraat Fakültesi Yayınları No:267, Ders Kitapları Serisi No:42, Erzurum.

Eroğlu, İ. 2007. Tuz stresinin bazı fasulye (Phaseolus vulgaris L.) kültür çeşitlerinde tohum çimlenmesi ve fide gelişimi üzerine etkileri. Yüksek Lisans Tezi, Ege Üniversitesi Fen Bilimleri Enstitüsü, s. 77, İzmir.

FAO, 2009. FAO Land and Plant Nutrition Management Service. http://www.fao.org/ag/agl/agll/spush/. . . Erişim: Kasım 2018).

Foster, K., H. Lambers, D. Real, P. Ramankutty, G.R. Cawthray1 \& M.H. Ryan, 2014. Drought resistance and recovery in mature Bituminaria bituminosa var. Albomarginata. Annals of Applied Biology ISSN 0003-4746.

Heath, R.L. and K., Packer, 1968. Leaf senesence; correlated with increased levels of membrane permeability and lipid peroxidation and decreased levels of superoxide dismutase and catalase. Journal of Experimental Botany, 32, 93-101.

Kara, T., 2002. Irrigation Scheduling to Prevent Soil Salinization from a Shallow Water Table, Acta Horticulture, Number 573, pp. 139-151.

Karakullukçu, E. ve Adak, S.I. 2008. Bazı nohut (Cicer arietinum L.) çeşitlerinin tuza toleranslarının belirlenmesi. Ankara Üniversitesi Ziraat Fakültesi Tarım Bilimleri Dergisi, 14 (4); 313-319.

Kaya, M.D., İpek, A. 2003. Effects of different soil salinity levels on germination and seedling growth of safflower (Carthamus tinctorius L.). Turk.J.Agric., 27; 221- 227.

Kusvuran, A., 2015. The effects of salt stress on the germination and antioxidative enzyme activity of Hungarian vetch (Vicia pannonica Crantz.) varieties. Legume Research, 38 (1): 51-59.

Lacerda, C.F., Cambrarı, J., Olıva, M.A., Ruız, H.A., Prisco, J.T., 2003. Solute Accumulation and Distribution During Shoot and Leaf Development in Two Sorghum Genotypes under Salt Stress. Environmental and Experimental Botany, 49: 107120.

Matysik, J.A., Bhalu, B. and Mohanty, P. 2002. Molecular mechanisms of quenching of reactive oxygen species by proline under stress in plants. Curr. Sci. 82, 525-532.
Önal Aşçı, Ö. ve Üney, H., 2016. Farklı tuz yoğunluklarının macar fiğinde (Vicia pannonica Crantz) çimlenme ve bitki gelişimine etkisi. Akademik Ziraat Dergisi 5 (1):29-34.

Öz, M. ve Karasu, A., 2007. Pamuğun çimlenmesi ve erken fide gelişimi üzerine tuz stresinin etkisi. UÜ Ziraat Fakültesi Dergisi, 21(1), 9-21.

Özaslan Parlak A., 2008. "Effect Of Salinity In Irrigation Water On Some Plant Development Parameters Of Sainfoin (Onobrychis Viciifolia Scop.) And Soil Salinization. Ankara Üniversitesi Ziraat Fakültesi Tarım Bilimleri Dergisi (Journal Of ", Ankara Üniversitesi Ziraat Fakültesi Tarım Bilimleri Dergisi, cilt.14, ss.320-325,

Shahid, M. A., Balal, R. M., Pervez, M. A., Abbas, T., Ashfaq, M., Ghazanfar, U., Afzal, M., Rashid, A., Garc'ia-Sanchez, F., and Mattson, N. S. 2012. Differential response of pea (Pisum sativum L.) genotypes to salt stress in relation to the growth, physiological attributes antioxidant activity and organic solutes. Aust. J. Crop Sci. 6: 828-838.

Sharma, D.P., Singh, K.N. and Kumbhare, P.S., 2005. Response of sunflower to conjunctive use of saline drainage water and non-saline canal water irrigation. Agronomy and Soil Science, Volume 51, Number 1, February 2005, pp. 91- 100(10).

Steppuhn,H., Volkmar, K.M and Miller, P.R., 2001. Comparing Canola. Field Pea, Dry Bean, and Durum Wheat Crops Grown in Saline Media. Crop Science, 41:1827-1833.

Talukdar D. 2013. Growth Responses and Leaf Antioxidant Metabolism of Grass Pea (Lathyrus sativus L.) Genotypes under Salinity Stress. ISRN Agronomy. 2013:1-15.

Wilson, C., LIU, X., Lesch, S.M., Suarez, D.L. 2006. Growth Response of Major U.S. Cowpea Cultivars. 1. Biomass Accumulation and Salt Tolerance. HortScience, 41 (1): 225-230.

Zeinali, E., Soltani, A. and Galeshi, S., 2002. Response of germination components to salinity stress in oil seed rape (Brassica napus L.), Iranian J. of Agric. Sci, 33, 137-45pp.

Zennouhi, O., Rfakı, A., El Mderssa, M., Bouiamrıne El H., Bijbijen J., Nassiri L. 2018. Effect Of Salinity And Temperature On The Seed Germination Of Bituminaria bituminosa var. bituminosa. International Journal of Current Research Vol. 10, Issue, 08, pp.72610-72613, August, 2018. 